\title{
The novel synthetic compound 6-acetyl-9-(3,4,5-trimetho- xybenzyl)-9H-pyrido[2,3- $b$ ]indole induces mitotic arrest and apoptosis in human COLO 205 cells
}

\author{
YI-CHIEN LIN ${ }^{1}$, JUI-YING TSAI ${ }^{1}$, JAI-SING YANG ${ }^{2}$, YUEH-HSUAN LEE ${ }^{1}$, ERNEST HAMEL $^{3}$, \\ KUO-HSIUNG LEE ${ }^{4,5}$, SHENG-CHU KUO ${ }^{1}$ and LI-JIAU HUANG ${ }^{1}$ \\ ${ }^{1}$ Graduate Institute of Pharmaceutical Chemistry, ${ }^{2}$ Department of Pharmacology, China Medical University, Taichung 40402, \\ Taiwan, R.O.C.; ${ }^{3}$ Screening Technologies Branch, Developmental Therapeutics Program, Division of Cancer Treatment \\ and Diagnosis, National Cancer Institute at Frederick, National Institutes of Health, Frederick, MD 21702; \\ ${ }^{4}$ Natural Products Research Laboratories, Eshelman School of Pharmacy, University of North Carolina, \\ Chapel Hill, NC 27599-7568, USA; ${ }^{5}$ Chinese Medicine Research and Development Center, \\ China Medical University Hospital, Taichung 40402, Taiwan, R.O.C.
}

Received July 5, 2013; Accepted July 29, 2013

DOI: 10.3892/ijo.2013.2069

\begin{abstract}
A novel synthetic compound 6-acetyl-9-(3,4,5trimethoxybenzyl)-9H-pyrido[2,3-b]indole (HAC-Y6) demonstrated selective anticancer activity. In the present study, COLO 205 cells were treated with HAC-Y6 to investigate the molecular mechanisms underlying its effects. HAC-Y6 induced growth inhibition, $\mathrm{G}_{2} / \mathrm{M}$ arrest and apoptosis in COLO 205 cells with an $\mathrm{IC}_{50}$ of $0.52 \pm 0.035 \mu \mathrm{M}$. Annexin V/PI double staining demonstrated the presence of apoptotic cells. JC-1 staining analysis showed that HAC-Y6 decreased mitochondrial membrane potential in support of apoptosis. An immunostaining assay revealed that HAC-Y6 depolymerized microtubules. Treatment of COLO 205 cells with HAC-Y6 resulted in increased expression of BubR1 and cyclin B1 and decreased expression of aurora A, phospho-aurora A, aurora B, phospho-aurora B and phospho-H3. HAC-Y6 treatment increased protein levels of active caspase-3, caspase-9, Endo G, AIF, Apaf-1, cytochrome $c$ and Bax, but treatment with the compound caused reduced levels of procaspase-3, procaspase-9, Bcl-xL and Bcl-2. Overall, our results suggest that HAC-Y6 exerts anticancer effects by disrupting microtubule assembly and inducing $\mathrm{G}_{2} / \mathrm{M}$ arrest, polyploidy and apoptosis via mitochondrial pathways in COLO 205 cells.
\end{abstract}

Correspondence to: Professor Li-Jiau Huang, Graduate Institute of Pharmaceutical Chemistry, China Medical University, No. 91 Hsueh-Shih Road, Taichung 40402, Taiwan, R.O.C.

E-mail: ljhuang@mail.cmu.edu.tw

Key words: 6-acetyl-9-(3,4,5-trimethoxybenzyl)-9H-pyrido[2,3-b] indole, $\alpha$-caboline derivative, human colon carcinoma COLO 205, mitotic arrest, apoptosis, aurora kinase

\section{Introduction}

Colorectal cancer is the third most commonly diagnosed cancer in men and the second in women, with over 1.2 million new cancer cases and 608,700 deaths estimated to have occurred worldwide in 2008 (1). Colorectal cancer is a multistep process, involving progressive disruption of intestinal epithelium growth (2). The disease arises as a result of the accumulation of genetic errors, many of which affect the control of apoptosis (3). Clinical treatment options for colorectal cancer consist of surgery, radiation and chemotherapy, but these treatments are often unsatisfactory (4).

Previous studies have reported that heat shock protein 90 (HSP90) inhibitors possess significant antitumor activity (5). HSP90 plays an essential role as a molecular chaperone, assisting in the correct folding of nascent and stress-accumulated misfolded proteins and preventing their aggregation (6). High HSP expression is a property of, and essential for the survival of, most cancers. Neutralizing HSPs could, thus, provide an alternative strategy for anticancer therapy (7).

Induction of cell cycle arrest and apoptosis are also potential strategies for cancer treatment. Investigators have widely explored the process of the cell cycle, particularly the CDK1/cyclin B1 complex, which plays an important role in the regulation of the $\mathrm{G}_{2} / \mathrm{M}$ phase. During pro-metaphase, spindle-assembly checkpoint proteins, such as BubR1, prevent anaphase and mitotic exit $(8,9)$. Anti-mitotic drugs that target microtubules have potential clinical application (10). Several studies have determined that microtubule-targeting agents act primarily to suppress spindle-microtubule dynamics, resulting in a blockade of metaphase/anaphase transition and the triggering of apoptotic cell death (11). The aurora kinase family is a collection of closely related serine/threonine kinases that are key regulators of mitosis $(12,13)$. Fu et al demonstrated upregulated aurora kinase expression and activity in cancer cells, indicating that aurora kinase might serve as a useful target for therapy (14). Three related 
aurora kinases have evolved in mammalian cells: aurora $\mathrm{A}$, aurora B, and aurora C $(13,15-18)$. Inhibition of aurora A or aurora B activity in tumor cells results in impaired chromosome alignment, abrogation of the mitotic checkpoint, polyploidy and subsequent cell death $(12,19,20)$. Apoptosis is a mechanism by which cells undergo programmed death to control cell proliferation or in response to DNA damage (21). Biochemical features of apoptosis include DNA fragmentation, protein cleavage at specific locations, increased mitochondrial membrane permeability and the appearance of phosphatidylserine (PS) on the cell membrane surface (22). The induction of apoptosis has formed the basis of several previous research investigations that focused on the selective killing of cancer cells (23).

Carbazole alkaloids are well-known natural compounds, some of which display anticancer activity (24-26). The $\beta$-carboline alkaloids occurring in medicinal plants have gained attention because of their antitumor effects (27). However, research on the anticancer activity of $\alpha$-carboline (isostere of $\beta$-carboline) derivatives is relatively limited. In a prior investigation, we synthesized a series of $\alpha$-carboline derivatives and identified several of them as novel anticancer agents. Among these, 6-acetyl-9-(3,4,5-trimethoxybenzyl)-9H-pyrido[2,3-b] indole (HAC-Y6) (Fig. 1) was the most potent. In the present study, HAC-Y6 was selected as a target compound and submitted to the National Cancer Institute (NCI, Bethesda, MD, USA) for further screening against a panel of 60 human tumor cell lines. Results indicated that HAC-Y6 is a promising anti-colon cancer agent. Further investigations of the molecular mechanisms of HAC-Y6's anti-human colon carcinoma effects, using COLO 205 cells as a model, were performed, and our results are presented here.

\section{Materials and methods}

Chemicals and reagents. HAC-Y6 was synthesized in the laboratory of the Graduate Institute of Pharmaceutical Chemistry, China Medical University (Taichung, Taiwan, R.O.C.). MTT (3-[4,5-dimethylthiazol-2-yl]-2,5-diphenyltetrazolium bromide), Hoechst 33258, propidium iodide (PI), Tris-HC1, Triton X-100, and RNase A were purchased from Sigma Chemical Co. (St. Louis, MO, USA). RPMI-1640 medium, L-glutamine, fetal bovine serum, penicillin-streptomycin, and trypsin-EDTA were obtained from Invitrogen Corp (Carlsbad, CA, USA). Antibodies for AIF, Apaf-1, aurora A, aurora B, phospho-aurora A, phospho-aurora B, Bcl-xL, BubR1, caspase-9, caspase-3, Endo G, phospho-H3, $\alpha$-tubulin, $\beta$-tubulin, and poly(ADP-ribose) polymerase (PARP) were purchased from Cell Signaling Technology (Beverly, MA,USA). Antibodies for $\beta$-actin, Bax, Bcl-2, cyclin B1, CDK1, cytochrome $c$, horseradish peroxidase (HRP)-linked goat anti-mouse IgG, and goat anti-rabbit IgG were purchased from Santa Cruz Biotechnology (Santa Cruz, CA, USA). The Annexin V-FITC Apoptosis Detection kit was obtained from Strong Biotech Corporation (Taipei, Taiwan, R.O.C.). The Flow Cytometry Mitochondrial Membrane Potential Detection kit was obtained from BD Biosciences (Los Angeles, CA, USA).

Cell culture. The human colon cancer cell line COLO 205 was obtained from the Food Industry Research and Development Institute (Hsinchu, Taiwan, R.O.C.). Cells were seeded into plates or dishes in RPMI-1640 medium supplemented with $10 \%$ fetal

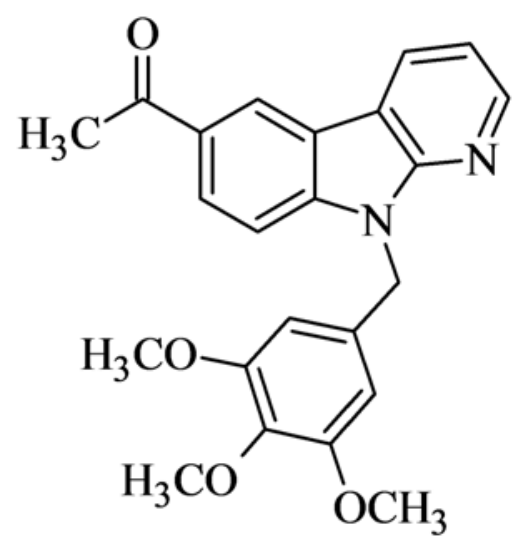

Figure 1. Chemical structure of HAC-Y6.

bovine serum, L-glutamine, $100 \mathrm{U} / \mathrm{ml}$ penicillin and $100 \mu \mathrm{g} / \mathrm{ml}$ streptomycin in a humid atmosphere of $5 \% \mathrm{CO}_{2}$ and $95 \%$ air at $37^{\circ} \mathrm{C}$. Cells were plated at a density of $2.5 \times 10^{4}$ cells per well in 96-well plates for the cell viability assay, $1 \times 10^{5}$ cells per well in 24-well plates with cover slips for Hoechst staining, $2 \times 10^{5}$ cells per well in 12-well plates for cell cycle assay, $1 \times 10^{6}$ cells per well in 6-well plates for mitochondrial membrane potential assay, and $1 \times 10^{7}$ cells per plate in $10 \mathrm{~cm}$ dishes for western blot analysis. Cells were allowed to adhere for $24 \mathrm{~h}$ before use.

Cell morphology. COLO 205 cells were plated at a density of $2.5 \times 10^{5}$ cells per well in 12-well plates and then incubated with $0.5 \mu \mathrm{M}$ of HAC-Y6 for 24 to $72 \mathrm{~h}$. Cells were directly examined and photographed under a phase contrast microscope.

Evaluation of cell viability using the MTT assay. COLO 205 cells were plated at a density of $2.5 \times 10^{4}$ cells per well in 96-well plates, and cell survival was evaluated using MTT reduction assays. The reduction status of the cells was measured by a colorimetric assay, indicating cell survival (28). MTT was dissolved in phosphate-buffered saline (PBS, $500 \mathrm{ml}$ contains $137 \mathrm{mM} \mathrm{NaCl}$, $2.7 \mathrm{mM} \mathrm{KCl}, 4.3 \mathrm{mM} \mathrm{Na} \mathrm{HPO}_{4}, 1.47 \mathrm{mM} \mathrm{KH}_{2} \mathrm{PO}_{4}, \mathrm{pH}$ 7.4) at a concentration of $1 \mathrm{mg} / \mathrm{ml}$ and filtered. After $48 \mathrm{~h}$ exposure to HAC-Y6, $50 \mu$ MTT was added to each well and incubated for $2 \mathrm{~h}$ at $37^{\circ} \mathrm{C}$ in the dark. When absorbed by living cells, MTT is converted to a water-insoluble blue product (formazan). The formazan product was dissolved by adding $150 \mu \mathrm{l}$ dimethylsulfoxide (DMSO) to each well. The absorption value at $570 \mathrm{~nm}$ was determined using an ELISA plate reader. Data are presented as the percentage of survival relative to vehicle-treated control culture. All measurements were performed in triplicate and each experiment was repeated at least three times.

Hoechst 33258 staining. Nuclei were stained with Hoechst 33258 (bis-benzimide, Sigma) to detect chromatin condensation or nuclear fragmentation, morphological characteristics of apoptosis. HAC-Y6 treatment cells were stained with $5 \mu \mathrm{g} / \mathrm{ml}$ Hoechst 33258 for 10 min. After washing twice with PBS, cells were fixed with $4 \%$ paraformaldehyde (PFA) in PBS for $10 \mathrm{~min}$ at $25^{\circ} \mathrm{C}$. Fluorescence of the soluble DNA (apoptotic) fragments was measured in a Varian Fluorometer at an excitation wavelength of $365 \mathrm{~nm}$ and emission wavelength of $460 \mathrm{~nm}$. 


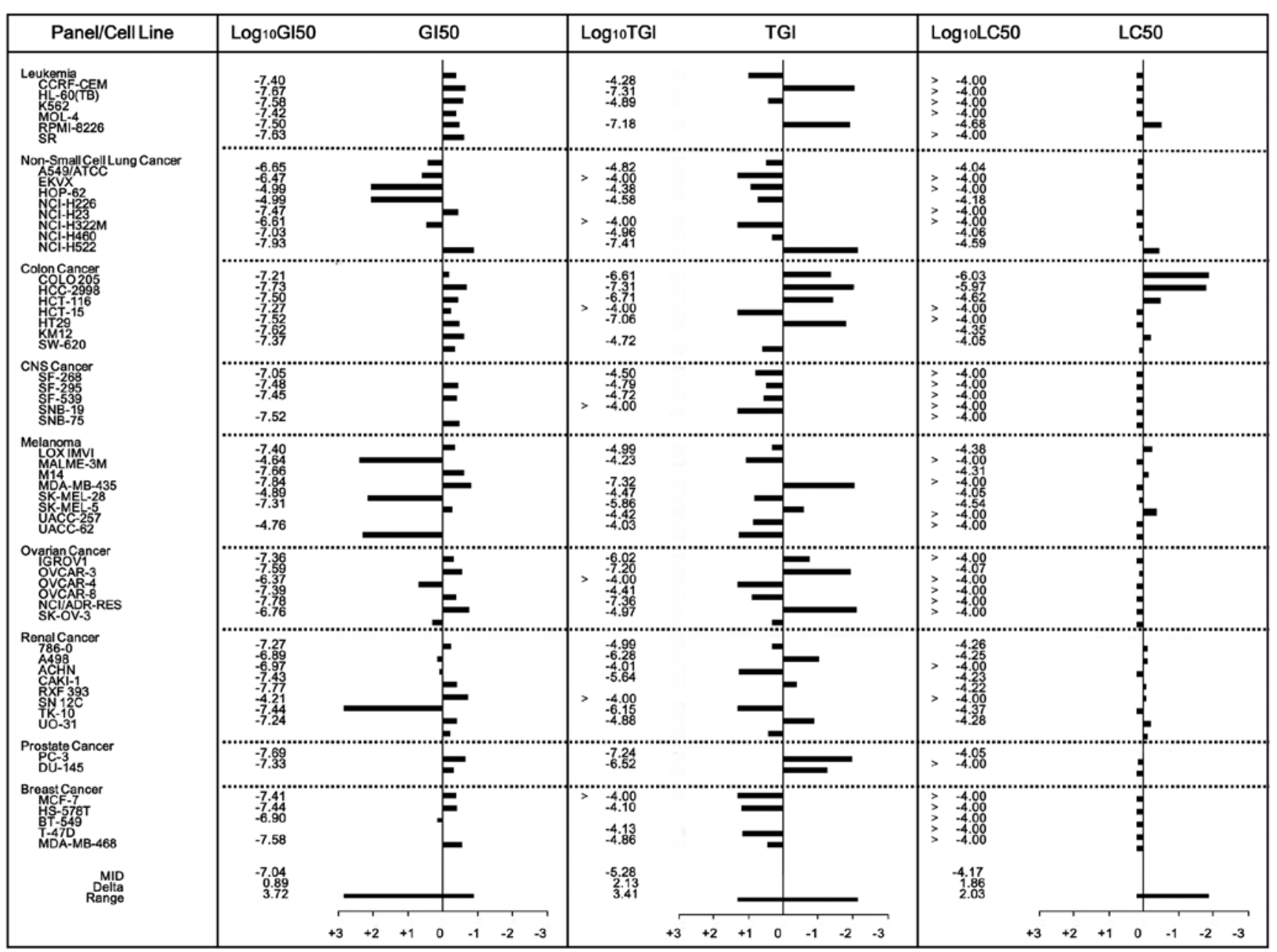

Figure 2. Effects of HAC-Y6 in the NCI 60 human tumor cell line panel.

Flow cytometric analysis for cell cycle effects. Cells were fixed in $70 \%$ ethanol overnight and re-suspended in PBS containing $20 \mu \mathrm{g} / \mathrm{ml} \mathrm{PI}, 0.2 \mathrm{mg} / \mathrm{ml}$ RNase A, and $0.1 \%$ Triton X-100 in a dark room. After $30 \mathrm{~min}$ incubation at $37^{\circ} \mathrm{C}$, cell cycle distribution was analyzed using ModFit LT Software (Verity Software House, Topsham, ME, USA) in a BD FACSCanto flow cytometer (Becton-Dickinson, San Jose, CA, USA).

Quantification of apoptosis. COLO 205 cells ( $2 \times 10^{5}$ cells/well) were fluorescently labeled for detection of apoptotic and necrotic cells by adding $100 \mu \mathrm{l}$ of binding buffer, $2 \mu 1$ of Annexin V-FITC, and $2 \mu \mathrm{l}$ of PI to each sample. Samples were mixed gently and incubated at room temperature in the dark for $15 \mathrm{~min}$. Binding buffer $(300 \mu \mathrm{l})$ was added to each sample immediately before flow cytometric analysis. A minimum of 10,000 cells within the gated region were analyzed.

Mitochondrial membrane potential analysis. Cells were plated on 6-well at $1.0 \times 10^{6}$ cells/well and treated with $1 \mu \mathrm{M}$ HAC-Y6 for 6-24 h. Mitochondrial membranes were stained with $0.5 \mathrm{ml}$ JC-1 working solution (BD MitoScreen Kit, Becton-Dickinson) to each sample. Samples were incubated for $10-15 \mathrm{~min}$ at $37^{\circ} \mathrm{C}$ in the dark. Mitochondrial membrane potential was measured using the BD FACSCanto flow cytometer (Becton-Dickinson).
Confocal microscopy. After treatment, cells were fixed with $4 \%$ PFA, blocked with $2 \%$ bovine serum albumin, stained with anti-tubulin monoclonal antibody, and then with FITC conjugated anti-mouse IgG antibody. PI was used to stain the nuclei. Cells were visualized using a Leica TCS SP2 Spectral Confocal System.

Tubulin assays. Tubulin assembly was measured through turbidimetry, as described previously (29). Assay mixtures containing $1.0 \mathrm{mg} / \mathrm{ml}(10 \mu \mathrm{M})$ tubulin and varying drug concentrations were preincubated for $15 \mathrm{~min}$ at $30^{\circ} \mathrm{C}$ in the absence of GTP. The samples were then placed on ice, and $0.4 \mathrm{mM} \mathrm{GTP}$ was added. Reaction mixtures were transferred to cuvettes held at $0^{\circ} \mathrm{C}$, and turbidity development was monitored for $20 \mathrm{~min}$ at $30^{\circ} \mathrm{C}$ after a rapid temperature increase. Drug concentrations that inhibited the increase in turbidity by $50 \%$ relative to a control sample were determined. Inhibition of the binding of $\left[{ }^{3} \mathrm{H}\right]$ colchicine to tubulin was measured as described previously (29). A total of $1.0 \mu \mathrm{M}$ tubulin was incubated with $5.0 \mu \mathrm{M}\left[{ }^{3} \mathrm{H}\right]$ colchicine and $5.0 \mu \mathrm{M}$ inhibitor for $10 \mathrm{~min}$ at $37^{\circ} \mathrm{C}$. At this time, approximately 40 to $60 \%$ of maximum colchicine binding occurred.

Western blot assay. The treated cells were collected and washed with PBS. After centrifugation, cells were lysed in a lysis buffer. 
A

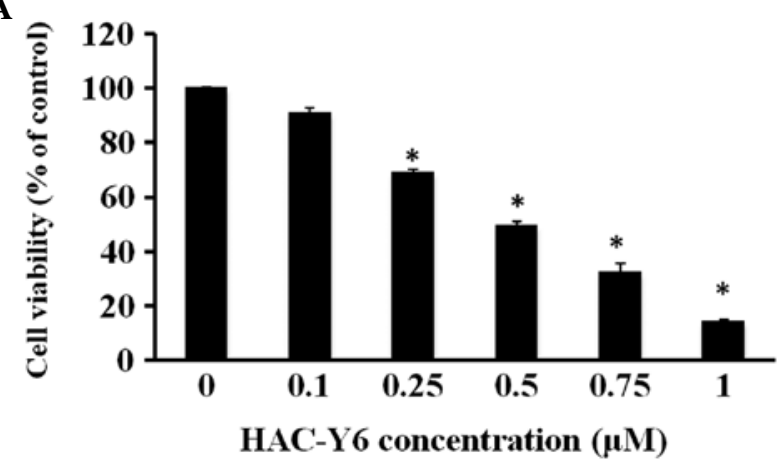

B

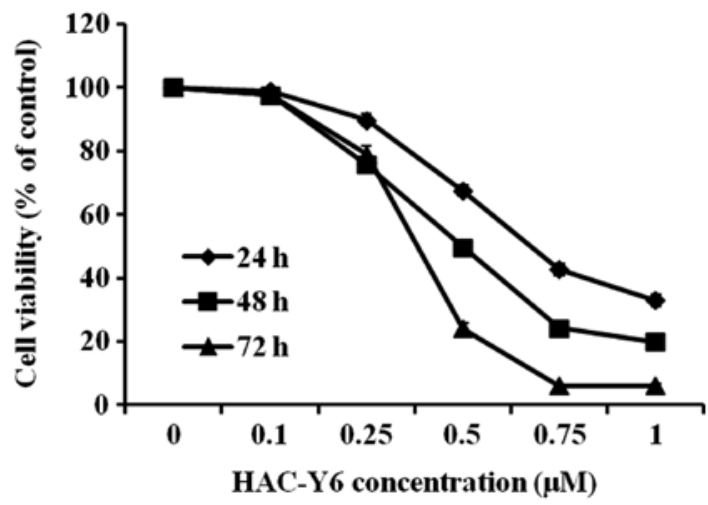

Figure 3. Effects of HAC-Y6 on viability of COLO 205 cells. (A) COLO 205 cells were exposed to different concentrations of HAC-Y6 for $48 \mathrm{~h}$. (B) COLO 205 cells were exposed to $0,0.1,0.25,0.5,0.75$ and $1 \mu \mathrm{M}$ HAC-Y6 for 24,48 and $72 \mathrm{~h}$, respectively. Cell viability was assessed using the MTT assay. The data are presented as mean \pm SEM of three independent experiments. Cells without treatment served as a control. ${ }^{*}<<0.001$ vs. control.

The lysates were incubated on ice for $30 \mathrm{~min}$ and centrifuged at $12,000 \mathrm{xg}$ for $20 \mathrm{~min}$. Supernatants were collected, and protein concentrations were then determined using the Bradford assay. After adding a $5 \mathrm{X}$ sample loading buffer containing $625 \mathrm{mM}$ Tris- $\mathrm{HCl}, \mathrm{pH} 6.8,500 \mathrm{mM}$ dithiothreitol, $10 \%$ SDS, $0.06 \%$ bromophenol blue, and $50 \%$ glycerol, protein samples were electrophoresed on 10\% SDS-polyacrylamide gels and transferred to a nitrocellulose membrane. Immunoreactivity was detected using the western blot chemiluminescence reagent system (PerkinElmer, Boston, MA, USA). $\beta$-actin was used as a loading control.

Statistical analysis. Statistical analysis was performed with an analysis of variance (ANOVA) followed by the Tukey's test. All data were expressed as mean \pm SD from at least three independent experiments. $\mathrm{P}<0.001$ was indicative of a significant difference.

\section{Results}

Growth inhibitory activity of HAC-Y6 against a panel of human cancer cell lines. Evaluation of the HAC-Y6 inhibitory activity against the NCI panel of 60 human cancer cell lines provided the results shown in Fig. 2. The mean graph midpoint (MID) values for the $\log \mathrm{GI}_{50}, \log \mathrm{TGI}$, and $\log \mathrm{LC}_{50}$ values were $-7.04,-5.26$ and -4.17 , respectively. For total growth inhibition (TGI), HAC-Y6 also demonstrated significant inhibitory activity $(\log$ TGI <-6.5) against 12 tumor cell lines: HL-60, RPMI-8228, NCI-H522, COLO 205, HCC-2998, HCT-116, HT29, MDA-MB-435, OVCAR-3, NCI/ADR-RES, PC-3 and DU145.

HAC-Y6 induces toxicity in COLO 205 cells. Exposure of COLO 205 cells to HAC-Y6 for $48 \mathrm{~h}$ and performance of MTT metabolism assays confirmed the effects of HAC-Y6 on cell viability. The $\mathrm{IC}_{50}$ value was $0.52 \pm 0.035 \mu \mathrm{M}$ with HAC-Y6 decreasing COLO 205 cell viability in a dose-dependent manner. Exposure of COLO 205 cells to 0.1, 0.25, 0.5, 0.75 and $1 \mu \mathrm{M}$ HAC-Y6 reduced the survival to $90.8 \pm 1.9,69.2 \pm 0.9$, $49.4 \pm 1.7,32.3 \pm 3.4$ and $14.1 \pm 1.1 \%$ of the control $(0.1 \%$ DMSO), respectively (Fig. 3A). HAC-Y6 inhibited COLO 205 cell growth dose- and time-dependently (Fig. 3B).
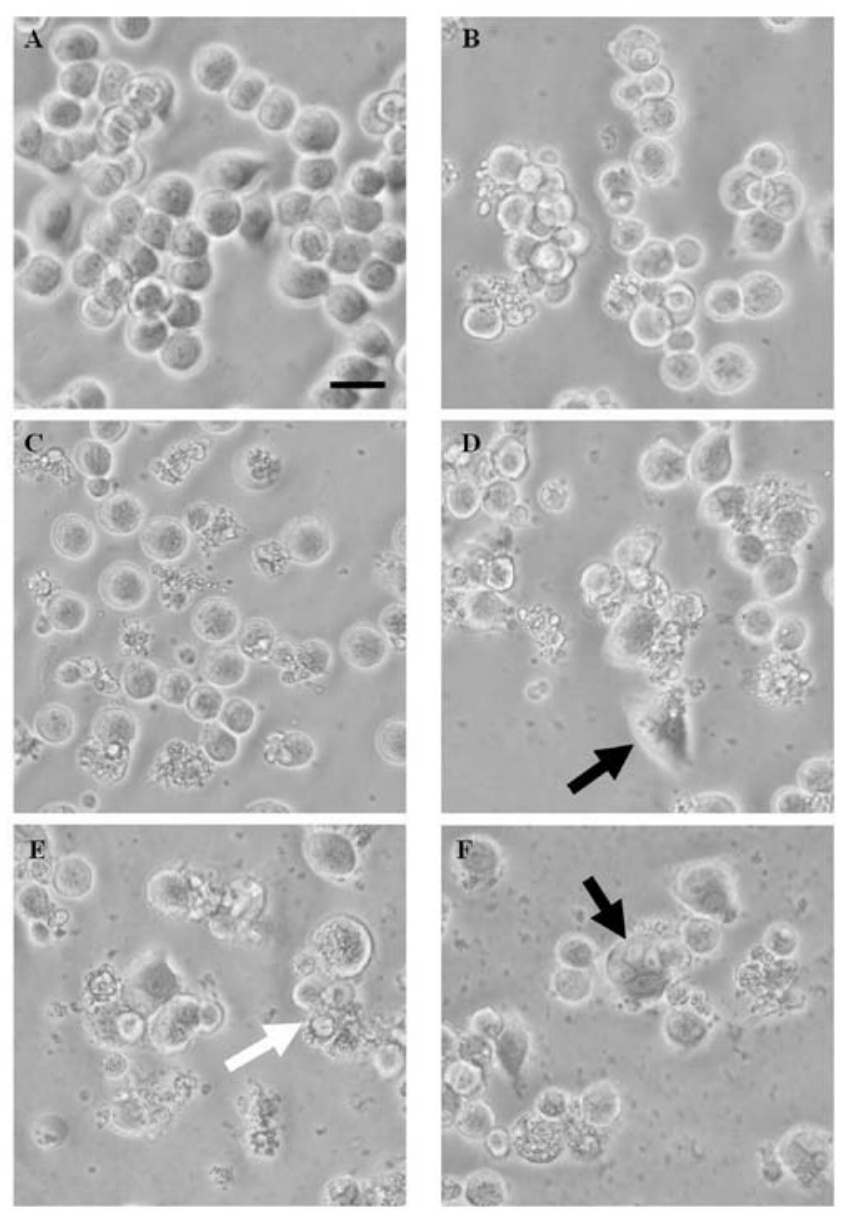

Figure 4. HAC-Y6 induces morphological changes in COLO 205 cells. COLO 205 cells were treated with $0.5 \mu \mathrm{M}$ HAC-Y6 for (B) 24, (C) 36 , (D) 48 , (E) 60 and (F) 72 h. (A) Cells without treatment served as a control. The white arrowhead indicates an apoptotic nucleus, and the black arrowheads indicate multinucleate cells. Scale bar, $20 \mu \mathrm{m}$.

HAC-Y6 induces morphological changes in COLO 205 cells. Morphological analysis confirmed the HAC-Y6 cytotoxic effects. As shown in Fig. 4, apoptotic morphological changes included cell rounding and shrinkage after $24 \mathrm{~h}$ incubation with $0.5 \mu \mathrm{M}$ of HAC-Y6 (the white arrowhead indicates an 

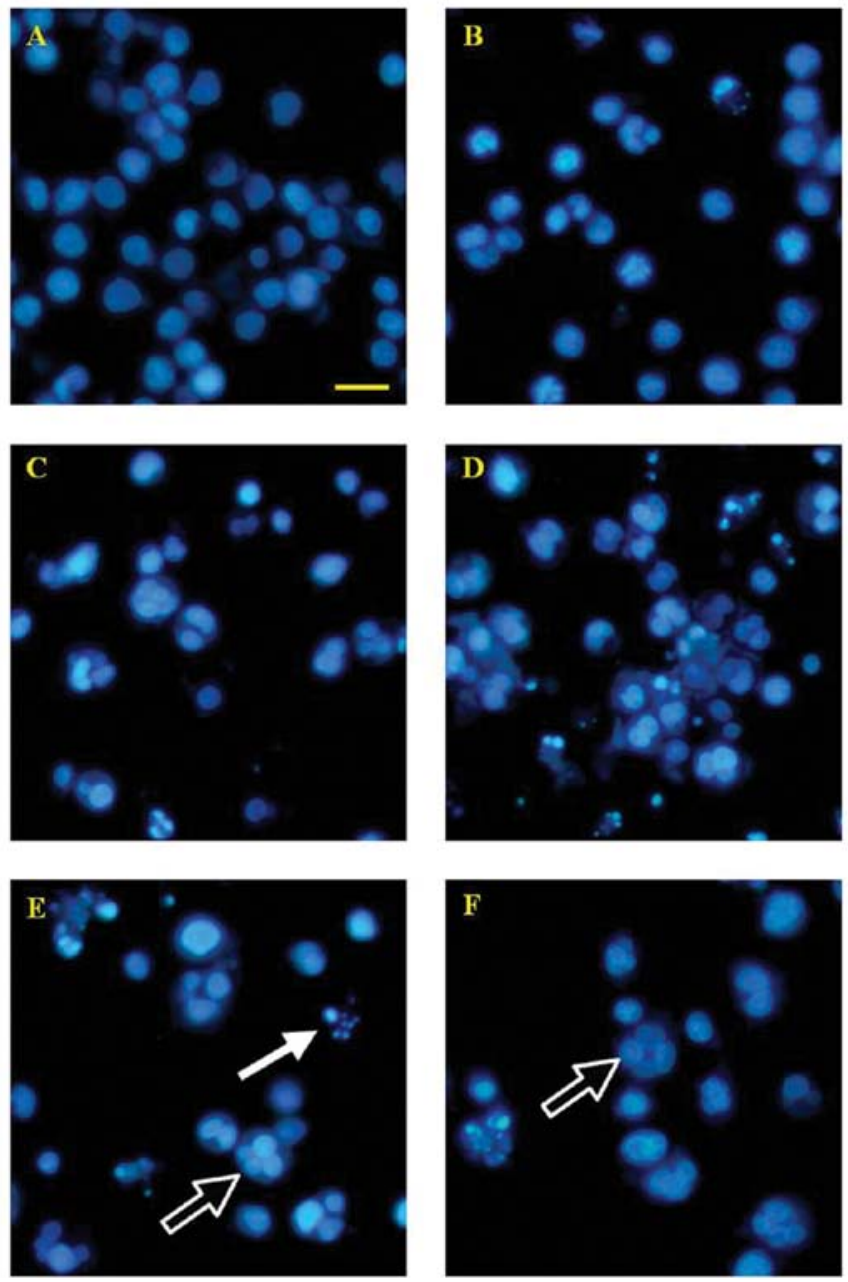

Figure 5. Fluorescent images of Hoechst staining showing HAC-Y6 induced cel death. COLO 205 cells were treated with $0.5 \mu \mathrm{M}$ HAC-Y6 for (B) 24, (C) 36, (D) 48, (E) 60 and (F) $72 \mathrm{~h}$ prior to Hoechst staining. (A) Cells without treatment served as a control. The white arrowhead indicates an apoptotic nucleus, and the black arrowheads indicate multinucleate cells. Scale bar, $20 \mu \mathrm{m}$.

apoptotic nucleus). Fig. 4D and F show COLO 205 cells with more than one nucleus per cell (the black arrowheads indicate multinucleate cells).

HAC-Y6 induces apoptosis in COLO 205 cells. Staining COLO 205 cells with Hoechst 33258 confirmed apoptosis as the cause of reduced cell viability. As shown in Fig. 5, control cells without HAC-Y6 treatment exhibited uniformly dispersed chromatin, normal organelles, and intact cell membranes. Cells treated with $0.5 \mu \mathrm{M}$ of HAC-Y6 for $24,36,48,60$ and $72 \mathrm{~h}$ demonstrated typical characteristics of apoptosis, including the condensation of chromatin, the shrinkage of nuclei and the appearance of apoptotic bodies (the white arrowhead indicates an apoptotic nucleus).

Annexin V-FITC/PI double-labeling detected phosphatidylserine externalization, a hallmark of the early phase of apoptosis (Fig. 6). Cells incubated in the absence of HAC-Y6 for $12,24,36$ and $48 \mathrm{~h}$ were undamaged and were negative for both Annexin V-FITC and PI staining (Q3). After incubation with $1 \mu \mathrm{M}$ HA-Y6 for 24 to $48 \mathrm{~h}$, the numbers of advanced apoptotic cells stained by positive Annexin V-FITC and
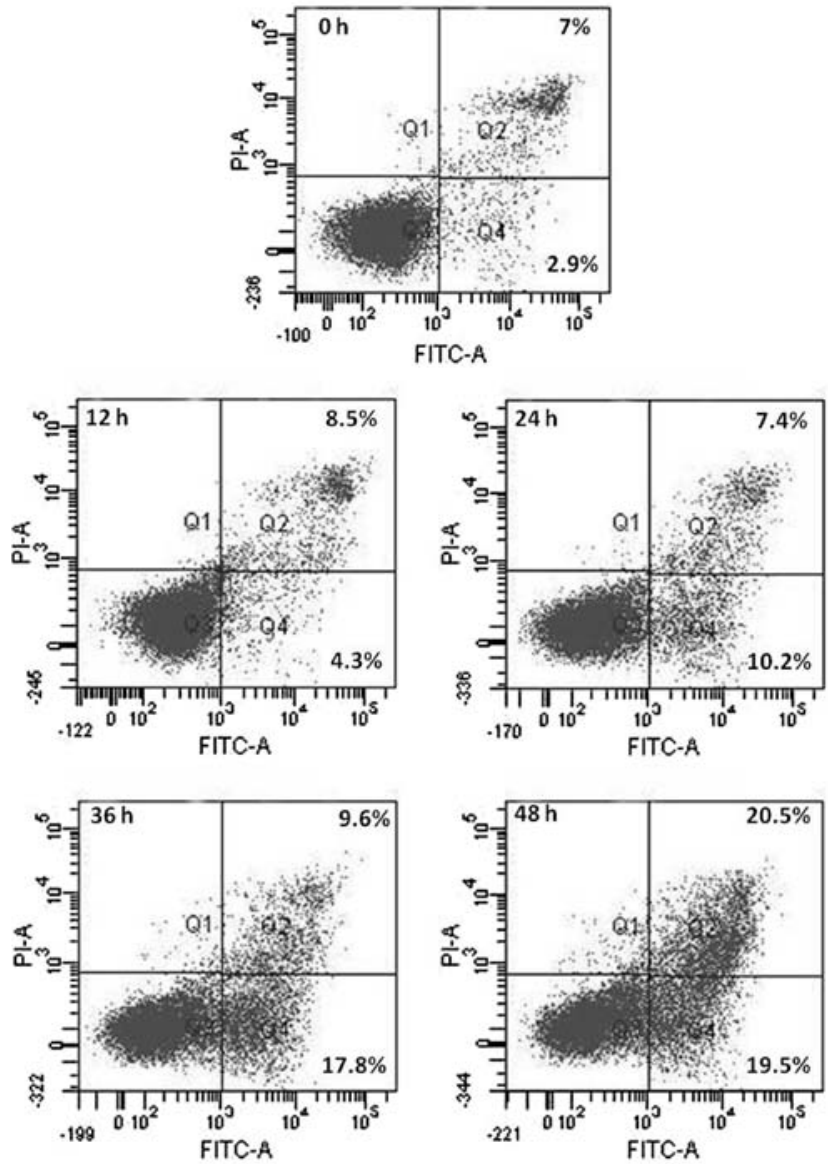

Figure 6. Confirmation of HAC-Y6-induced apoptotic cell death. COLO 205 cells were treated with HAC-Y6 for different periods of time and apoptosis was assessed using Annexin V/PI staining and flow cytometry. The fraction of Annexin V-positive COLO 205 cells was $2.9 \%$ prior to treatment and 4.3 , 10.2, 17.8 and $19.5 \%$ after treatment with HAC-Y6 for 12, 24, 36 and $48 \mathrm{~h}$, respectively.
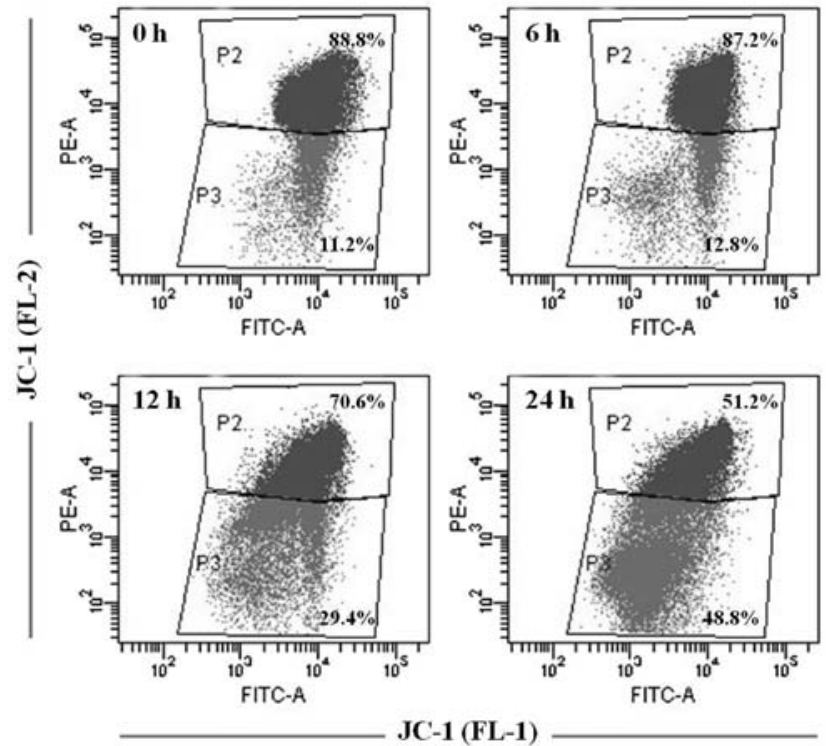

Figure 7. Effects of HAC-Y6 on mitochondrial membrane potential in COLO 205 cells. Cells $\left(1 \times 10^{6}\right.$ cells $\left./ \mathrm{ml}\right)$ were untreated or treated with HAC-Y6 $(1 \mu \mathrm{M}$, 6-24 h) to induce apoptosis. Cells were stained with JC-1 according to the protocol on a $\mathrm{BD}^{\mathrm{TM}}$ MitoScreen as described in Materials and methods for staining cells with JC-1 and analyzing by flow cytometry. 
A
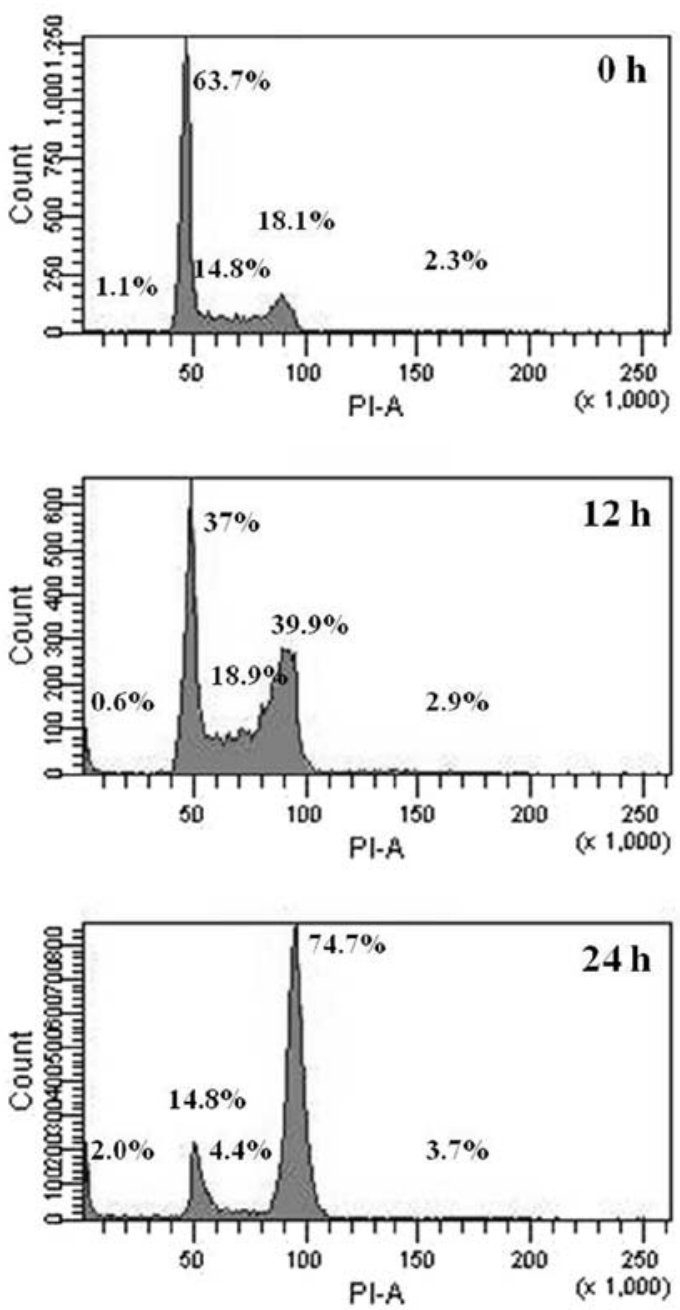

B

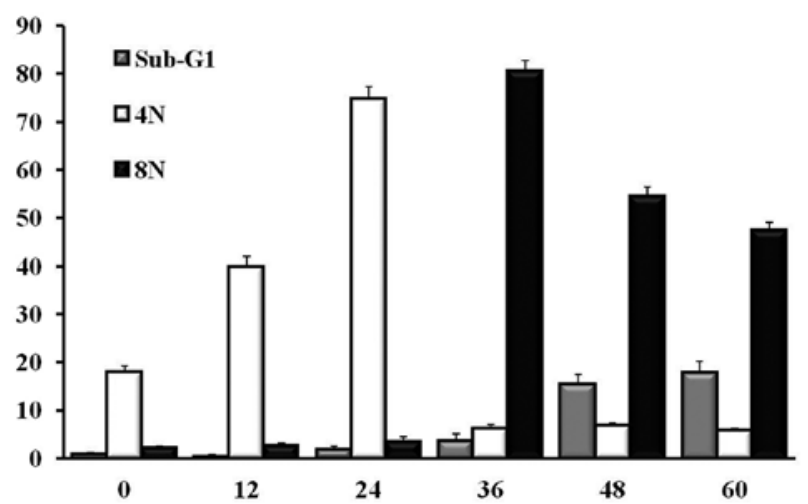

negative PI (Q4) were significantly increased as the incubation time grew longer. The numbers of advanced apoptotic cells stained by positive Annexin V-FITC and PI (Q2) also increased significantly with incubation time.

During apoptosis, the mitochondrial membrane potential $(\Delta \psi m)$ decreases. Cells treated with $1 \mu \mathrm{M}$ of HAC-Y6 for 6,12 and $24 \mathrm{~h}$, stained cells with JC-1 confirmed apoptosis as the cause of decreased $\Delta \psi m$. As shown in Fig. 7, JC-1 fluorescence is seen in both the FL2 and FL1 channel (P2) in the control cell population $(0 \mathrm{~h})$. There is a significant increase in the number of cells with reduced red fluorescence (P3), indicative
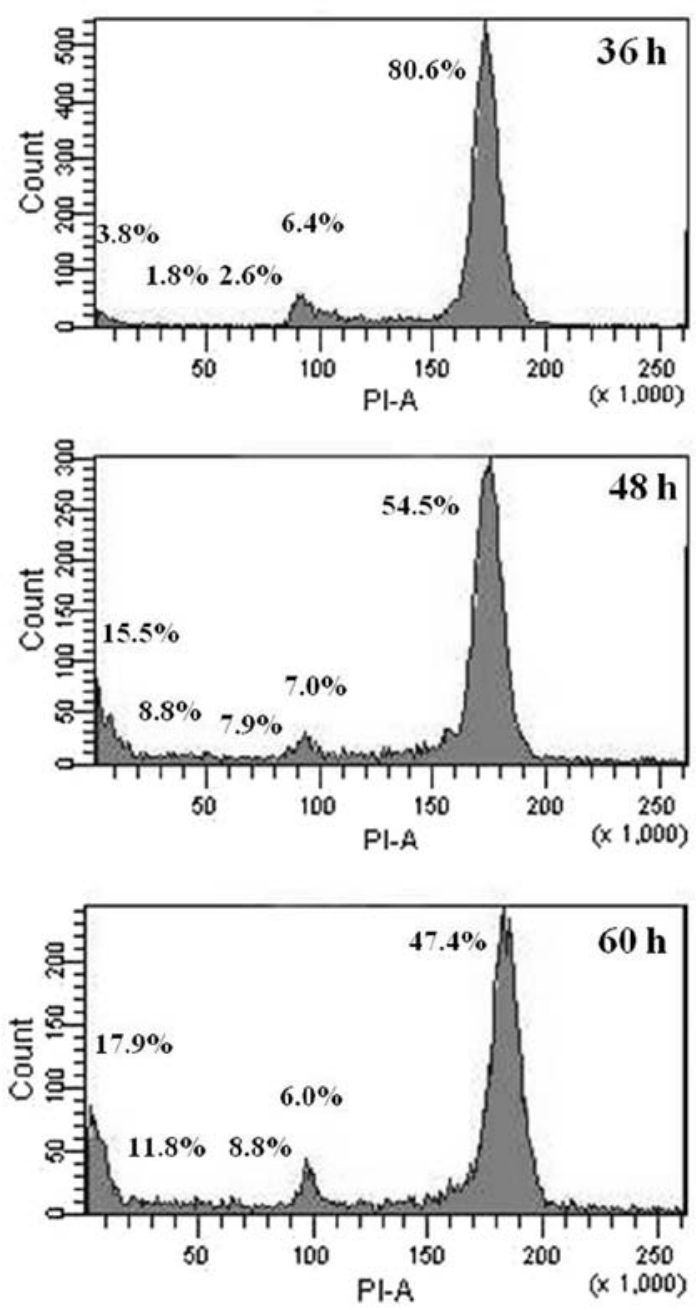

Figure 8. Effects of HAC-Y6 on the cell cycle in COLO 205 cells. (A) COLO 205 cells were incubated with $1 \mu \mathrm{M}$ of HAC-Y6 for $0,12,24,36,48$ and $60 \mathrm{~h}$, respectively. They were then harvested and analyzed using flow cytometry. (B) Bar graph representation of the cell cycle distribution and percentages of sub-G1, $4 \mathrm{~N}$ and $8 \mathrm{~N}$ populations.

of a change in the $\Delta \psi m$, in the population induced to undergo apoptosis (6-24 h). These data demonstrate that HAC-Y6 induced cell apoptosis in COLO 205 cells.

HAC-Y6 induces $G_{2} / M$ arrest, multinucleation and apoptosis in COLO 205 cells. Treatment of COLO 205 cells with $1 \mu \mathrm{M}$ of HAC-Y6 for 0, 12, 24, 36, 48 and $60 \mathrm{~h}$, followed by flow cytometric analysis to determine cell cycle distribution of the treated cells, was used to investigate the effects of HAC-Y6 on disruption of the cell cycle and provide further insights into the apoptotic effects of the compound. As shown in Fig. 8, HAC-Y6 induced a time-dependent accumulation of $\mathrm{G}_{2} / \mathrm{M}(4 \mathrm{~N})$ cells, as well as causing formation of octoploid cell ( $8 \mathrm{~N})$ population and apoptotic (sub- $\mathrm{G}_{1}$ ) cells. These flow cytometric findings with HAC-Y6-treated COLO 205 cells are in accord with the multinucleated cells presented above (Figs. 4D, F and 5; the black arrowheads indicate multinucleate cells).

HAC-Y6 inhibites tubulin polymerization. COLO 205 cells were treated with $1 \mu \mathrm{M}$ of HAC-Y6 for $24 \mathrm{~h}$ and then stained 
A

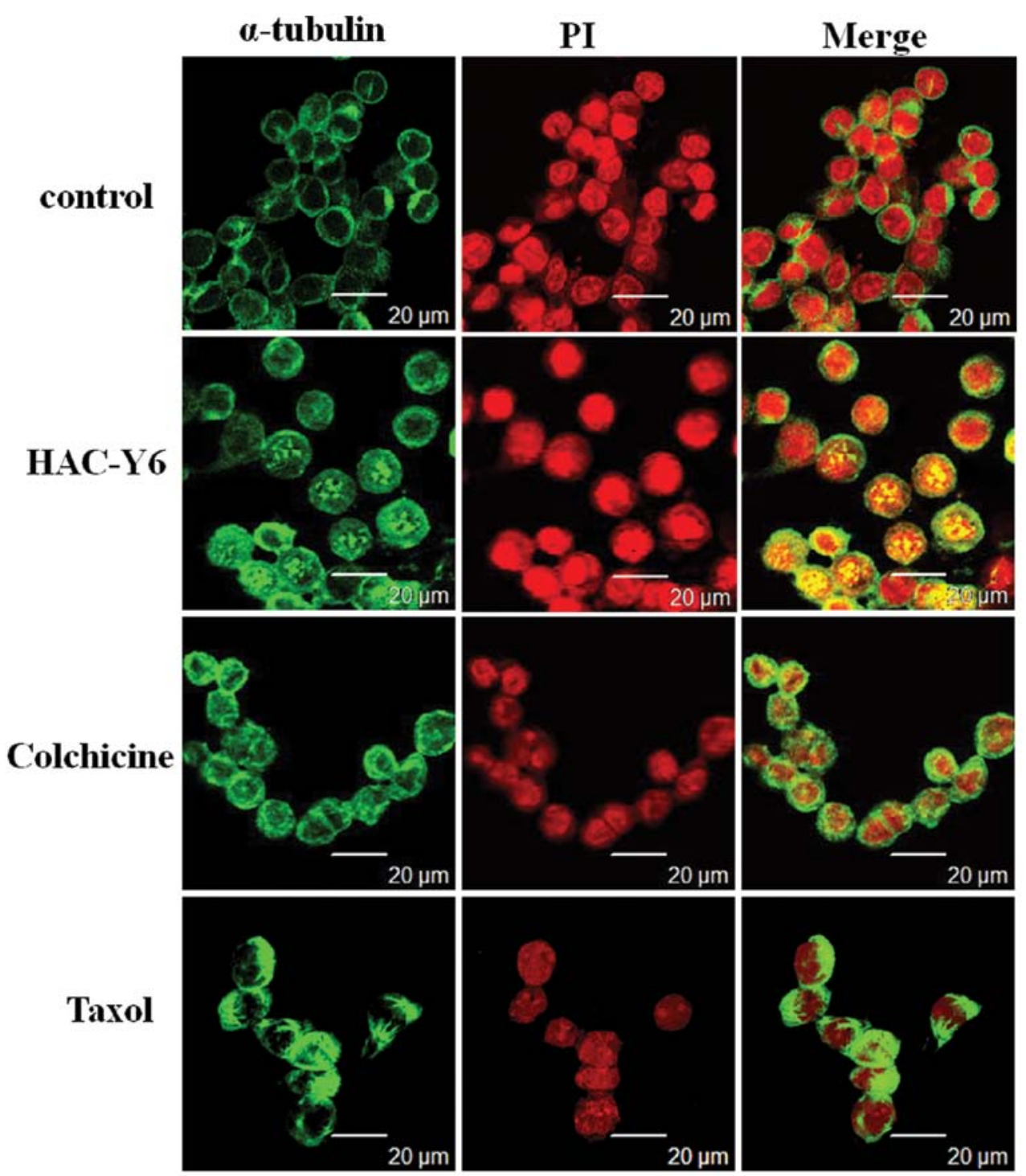

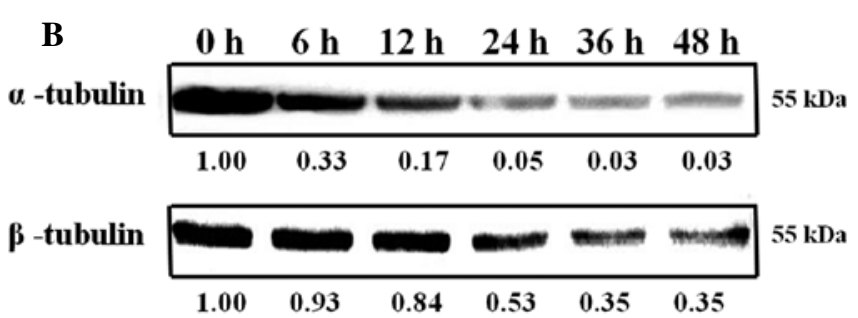

$\beta$-actin

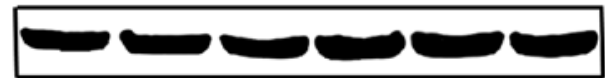

appropriately and examined in a confocal microscope to determine the effects of the compound on the cellular microtubule cytoskeleton. As shown in Fig. 9A, treatment with HAC-Y6 resulted in microtubule changes similar to those induced by colchicine. Both compounds caused cellular microtubule depolymerization with short microtubule fragments scattered throughout the cytoplasm. Taxol, in contrast, induced significantly increased tubulin polymerization. As shown in Fig. 9B, after cells were treated with HAC-Y6 for 6-48 h, HAC-Y6 caused inhibition of microtubule ( $\alpha$ - and $\beta$-tubulin) assembly. Therefore,
Figure 9. HAC-Y6 causes microtubule disassembly in cultured cells. (A) Confocal staining was performed on COLO 205 cells without treatment and following treatment with $1 \mu \mathrm{M}$ of HAC-Y6, $1 \mu \mathrm{M}$ colchicine or $1 \mu \mathrm{M}$ taxol. Cells were fixed, permeabilized and stained with anti- $\alpha$-tubulin monoclonal antibody. Cells were visualized using confocal microscopy. (B) HAC-Y6 decreased microtubule ( $\alpha$ - and $\beta$-tubulin) protein expression by western blot analysis. At least three independent experiments were performed obtaining similar results. $\beta$-actin was used as a loading control.

our data demonstrated that HAC-Y6 induced microtubule depolymerization.

Further examination of HAC-Y6 in tubulin assays and comparison with combretastatin A-4 (CA-4) provided the results presented in Table I. HAC-Y6 potently inhibited tubulin assembly, with an $\mathrm{IC}_{50}$ value of $0.81 \pm 0.03 \mu \mathrm{M}$. Although HAC-Y6 inhibited tubulin assembly more potently than CA-4 $\left(\mathrm{IC}_{50} 1.3 \pm 0.1 \mu \mathrm{M}\right)$, it was slightly less effective than CA-4 in inhibiting colchicine binding to tubulin.

Increased BubRl and inhibition of aurora kinase by HAC-Y6 associated with $G_{2} / M$ cell cycle arrest. Cyclin B1 and CDK1 are markers for induction of mitotic arrest. Treatment of 
Table I. Anti-tubulin data for HAC-Y6.

\begin{tabular}{lcc}
\hline & $\begin{array}{c}\text { Inhibition } \\
\text { of tubulin } \\
\text { assembly } \text { IC }_{50} \\
(\mu \mathrm{M}) \pm \mathrm{SD}\end{array}$ & $\begin{array}{c}\text { Inhibition of colchicine } \\
\text { binding with } 5 \mu \mathrm{M} \\
\text { inhibitor } \%\end{array}$ \\
inhibition $\pm \mathrm{SD}$
\end{tabular}

${ }^{\mathrm{a}}$ Assembly assay contained $10 \mu \mathrm{M}$ tubulin. ${ }^{\mathrm{b}}$ Colchicine binding assay contained $1 \mu \mathrm{M}$ tubulin and $5 \mu \mathrm{M}\left[{ }^{3} \mathrm{H}\right]$ colchicine.

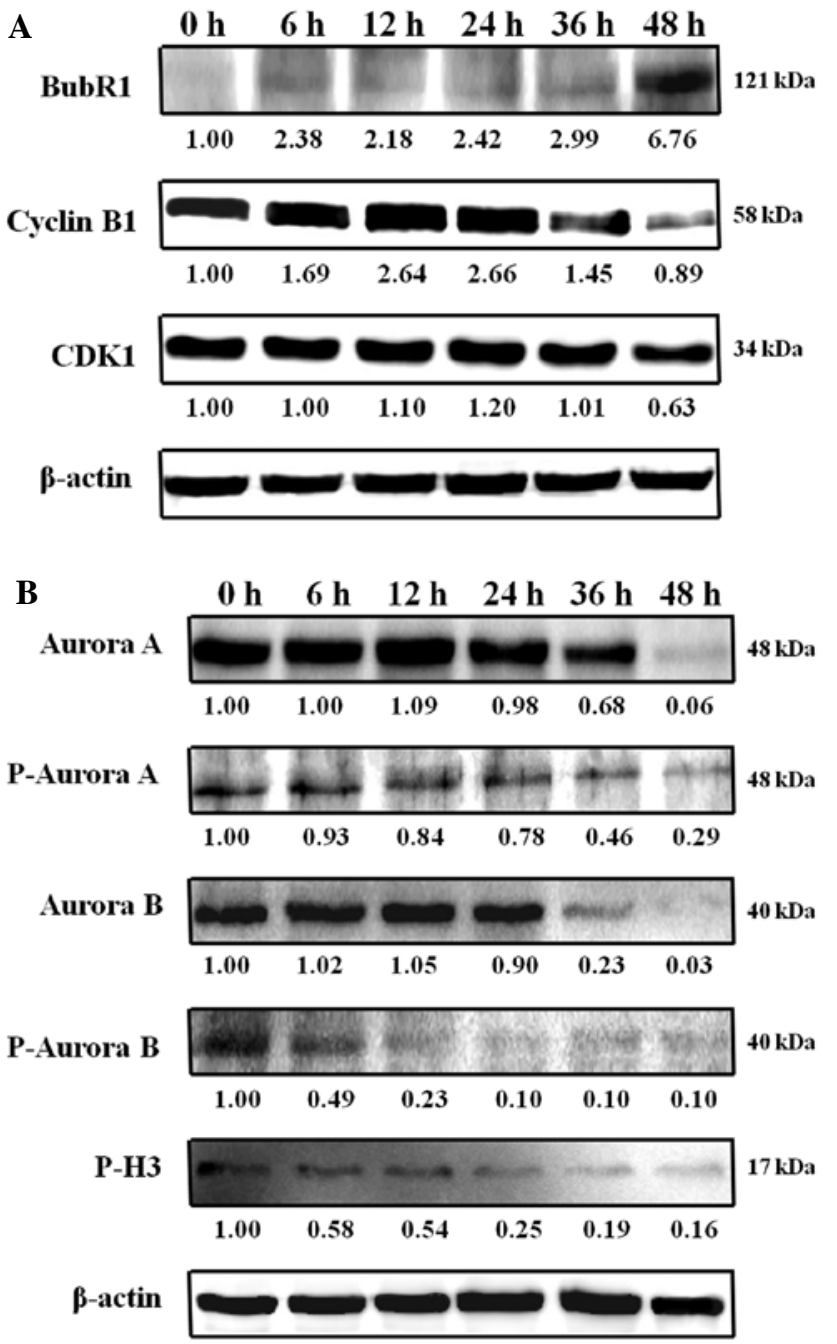

Figure 10 . HAC-Y6 increased $\mathrm{G}_{2} / \mathrm{M}$ phase checkpoint protein expression. COLO 205 cells were treated with $1 \mu \mathrm{M}$ HAC-Y6 for the indicated time periods and lysed for protein extraction. Protein samples ( $40 \mu \mathrm{g}$ protein/lane) were separated using $10 \%$ SDS-PAGE and subjected to immunoblot analysis with antibodies specific to (A) BubR1, cyclin B1, CDK1; and (B) aurora A, phospho-aurora A, aurora B, phospho-aurora B and phospho-H3. At least three independent experiments were performed obtaining similar results. $\beta$-actin was used as a loading control.

COLO 205 cells with $1 \mu \mathrm{M}$ of HAC-Y6 increased cyclin B1 protein levels (Fig. 10A). BubR1, an essential component of the mitotic check-point, localizes in kinetochores (8). Treatment
A

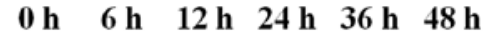

Procaspase 3

Cleaved caspase 3

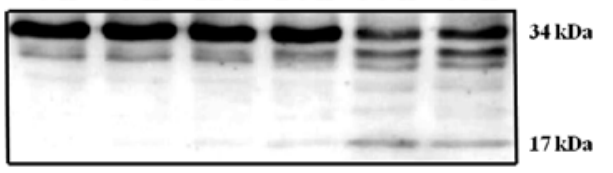

Procaspase 9

Cleaved caspase 9
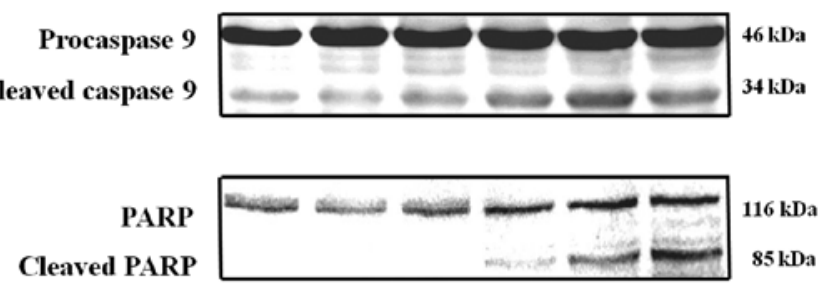

$\beta$-actin

B

$\begin{array}{llllllll}\text { 0h } & 6 \mathrm{~h} & 12 \mathrm{~h} & 24 \mathrm{~h} & 36 \mathrm{~h} & 48 \mathrm{~h}\end{array}$

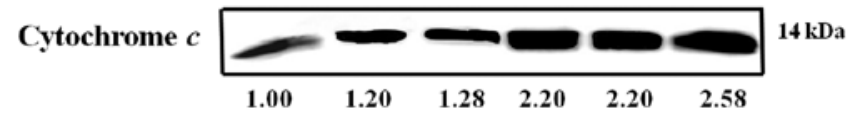

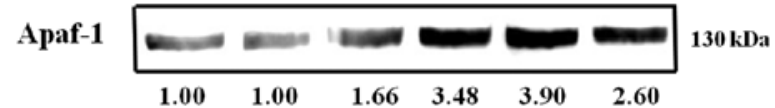

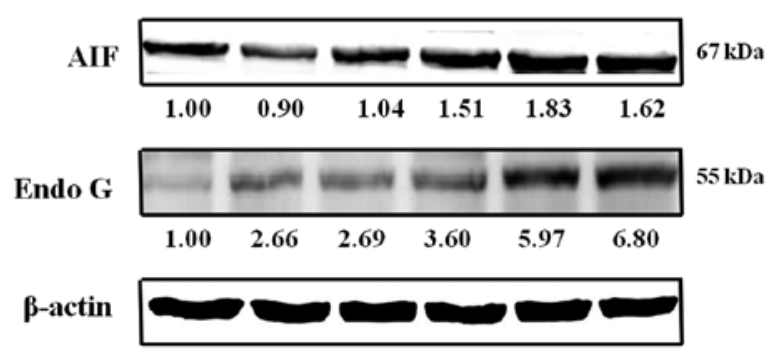

Figure 11. HAC-Y6 induces apoptotic pathways in COLO 205 cells. COLO 205 cells were treated with $1 \mu \mathrm{M}$ of HAC-Y6 for the indicated times and lysed for protein extraction. Protein samples ( $40 \mu \mathrm{g}$ protein/lane) were separated using 10\% SDS-PAGE and subjected to immunoblot analysis with antibodies specific to (A) PARP, caspase-3, caspase-9; and (B) cytochrome $c$, Apaf-1, AIF and Endo G. At least three independent experiments were performed obtaining similar results. $\beta$-actin was used as a loading control.

of COLO 205 cells with $1 \mu \mathrm{M}$ HAC-Y6 increased the levels of BubR1 (Fig. 10A). This result suggests that BubR1 contributed to activation of the mitotic checkpoint induced by HAC-Y6. The compound directly causes microtubule disassembly, and the cell cycle protein changes, including increased BubR1 expression, are secondary to the failure to form a spindle, which results from disruption of tubulin assembly.

Treatment of COLO 205 cells with $1 \mu \mathrm{M}$ HAC-Y6 was used to investigate the effects of HAC-Y6 on aurora kinase function. As shown in Fig. 10B, HAC-Y6 decreased aurora A, phospho-aurora A, aurora B and phospho-aurora B expression. Histone $\mathrm{H} 3$ is one of the substrates of aurora $\mathrm{B}$ kinase. During mitosis, aurora B is required for phosphorylation of histone $\mathrm{H} 3$ on serine 10, and this might be important for chromosome condensation (15). We therefore examined whether HAC-Y6 inhibited phosphorylation of histone $\mathrm{H} 3$ in COLO 205 cells by western blot analysis. As shown in Fig. 10B, HAC-Y6 decreased phospho-H3 expression after 


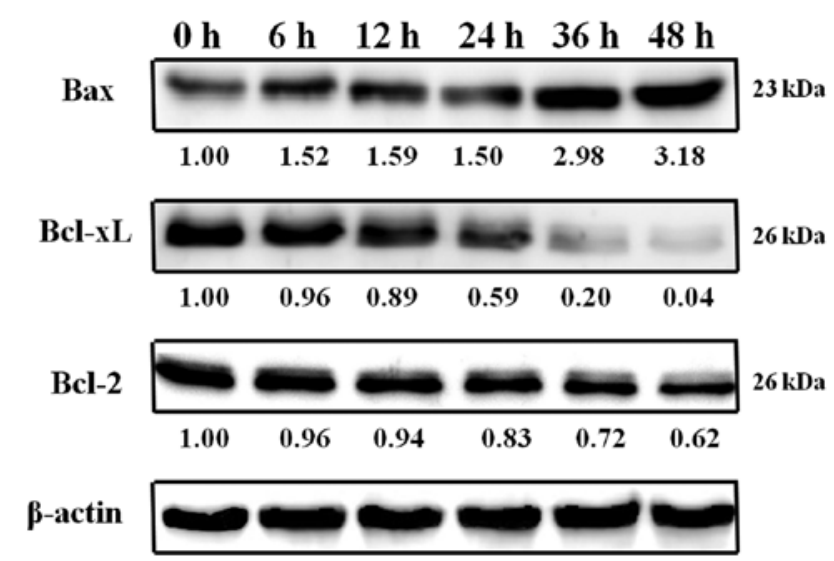

Figure 12. HAC-Y6 affects Bcl-2 family proteins in COLO 205 cells. COLO 205 cells were treated with $1 \mu \mathrm{M}$ of HAC-Y6 for the indicated times and lysed for protein extraction. Protein samples (40 $\mu \mathrm{g}$ protein/lane) were separated using $10 \%$ SDS-PAGE and subjected to immunoblot analysis with antibodies specific to Bax, Bcl-xL and Bcl-2. At least three independent experiments were performed obtaining similar results. $\beta$-actin was used as a loading control.

a $6 \mathrm{~h}$ treatment. This finding suggests that inactivation of aurora kinases A and B is involved in HAC-Y6-induced $\mathrm{G}_{2} / \mathrm{M}$ arrest and multinucleation.

HAC-Y6 induces apoptosis via activation of mitochondrial signaling pathways and affects Bcl-2 family proteins in COLO 205 cells. Following our observations that HAC-Y6 caused apoptosis in COLO 205 cells, we next determined levels of selected proteins associated with apoptosis. The activation of caspases is a hallmark of apoptosis. Activated caspases cleave a variety of target proteins including poly(ADP-ribose) polymerase, DNA-dependent protein kinase, and sterol regulatory-dependent binding protein, and thereby disable cellular processes and break down the cellular structure (23). To investigate whether HAC-Y6-induced apoptosis was involved in the activation of caspase cascades, COLO 205 cells were exposed to $1 \mu \mathrm{M}$ of HAC-Y6 for $6,12,24,36$ and $48 \mathrm{~h}$. The activities of caspase- 3 and caspase- 9 were then determined using Western blot analysis, which revealed activation of caspase- 3 and caspase- 9 within $12 \mathrm{~h}$ of HAC-Y6 treatment. Cleavage of PARP, a substrate for caspase-3, also occurred (Fig. 11A). HAC-Y6 also increased levels of Endo G, AIF, Apaf-1 and cytochrome $c$ (Fig. 11B). These results suggest that the mitochondrial signaling pathways of COLO 205 cells mediate HAC-Y6-induced apoptosis.

The Bcl-2 family proteins are key regulators of mitochondrial-related apoptotic pathways (30). Some of these proteins (such as Bcl-2 and Bcl-xL) are anti-apoptotic, whereas others (such as Bad, Bax and Bid) are pro-apoptotic. The balance of pro- and anti-apoptotic bcl-2 proteins influences the sensitivity of cells to apoptotic stimuli (31). Exposure of COLO 205 cells to $1 \mu \mathrm{M}$ of HAC-Y6 for $6,12,24,36$ and $48 \mathrm{~h}$ verified the involvement of Bcl-2 protein activity in HAC-Y6-induced apoptosis. As shown in Fig. 12, results indicated that HAC-Y6 reduced anti-apoptotic Bcl-2 and Bcl-xL levels, as well as increased pro-apoptotic Bax levels and the release of Endo G, AIF, Apaf-1, cytochrome $c$ and procaspase-9 from the mitochondria to the cytosol. Release of Apaf-1, and cytochrome $c$ leads to the activation of caspase-9. Activated caspase-9, in turn, cleaves and activates caspase-3.

\section{Discussion}

Derivation of new drugs from natural products involves the synthesis of new compounds by modifying the structural skeletons of the natural products. Several reports have demonstrated that carbazole alkaloids exhibit anticancer activity (24-26). $\alpha$-carboline is a bioisostere of carbazole, where the benzene ring of carbazole is replaced by a pyridine ring, and previous studies have described the anticancer effects of its derivatives $(32,33)$. In this study, we describe the anticancer mechanisms of the novel $\alpha$-carboline derivative HAC-Y6.

The NCI results for HAC-Y6 presented in Fig. 2 indicated potent inhibitory activity against multiple cancer cell lines. The $\mathrm{LC}_{50}$ values, however, indicated selective inhibition of

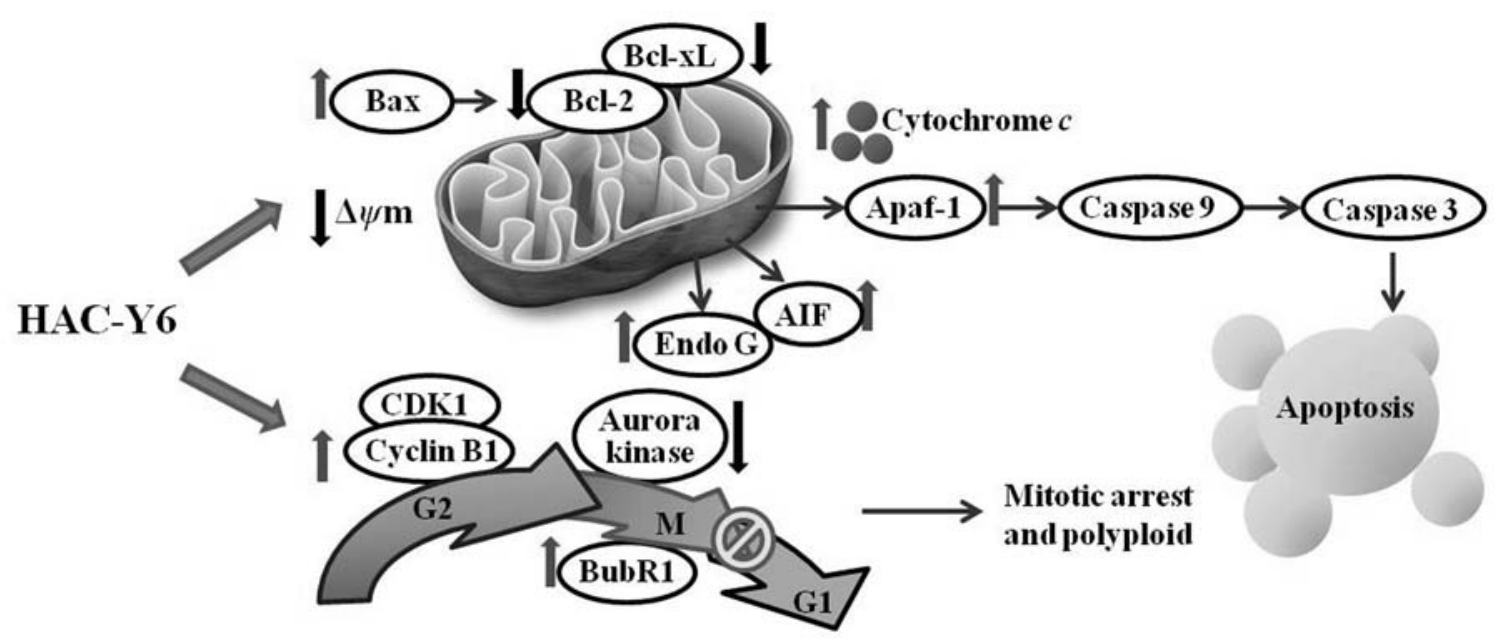

Figure 13. The proposed model by which HAC-Y6 induces $\mathrm{G}_{2} / \mathrm{M}$ phase arrest, polyploidy and apoptosis in COLO 205 cells. 
COLO 205 and HCC 2998 colon cancer cells, with $\log \mathrm{LC}_{50}$ values of -6.3 and -5.97 , respectively; potencies that are approximately 100 times the average value (-4.17). These results prompted our further investigation of the effects of the compound on COLO 205 cells.

Investigation of the anticancer activity of HAC-Y6 in COLO 205 cells provided data indicating that HAC-Y6 induced cytotoxicity in COLO 205 cells in a dose- and time-dependent manner (Fig. 3), acting through $\mathrm{G}_{2} / \mathrm{M}$ arrest, polyploidy and apoptosis (Fig. 8). Annexin V/PI double staining demonstrated the presence of apoptotic cells in HAC-Y6-treated COLO 205 cells (Fig. 6). Mitochondrial membrane potential analysis showed that HAC-Y6 induced mitochondrial membrane potential in support of apoptosis in COLO 205 cells (Fig. 7).

Microtubules are important cellular targets for anticancer therapy, because of their key role in mitosis (34). In this study, HAC-Y6 induced the depolymerization of microtubules in COLO 205 cells. Treatment with HAC-Y6 for $24 \mathrm{~h}$ resulted in microtubule changes similar to those induced by colchicine (Fig. 9A). HAC-Y6 caused inhibition of microtubule ( $\alpha$ - and $\beta$-tubulin) assembly (Fig. 9B). HAC-Y6 can thus be classified as a microtubule-depolymerizing agent.

Previous investigations have reported that cyclin B1/CDK1 complexes are involved in the regulation of $\mathrm{G}_{2} / \mathrm{M}$ phase and M-phase transitions $(9,35)$. HAC-Y6 initiated induction of $\mathrm{G}_{2} / \mathrm{M}$ phase arrest (4N) within 12 to $24 \mathrm{~h}$ and polyploidy (8N) within 36 to $60 \mathrm{~h}$ of treatment (Fig. 8B). Our data showed increased levels of cyclin B1 after HAC-Y6 treatment (Fig. 10A). HAC-Y6 arrested the growth of COLO 205 cells at the $\mathrm{G}_{2} / \mathrm{M}$ phase through the accumulation of cyclin B1. BubR1 is a key component of the mitotic spindle checkpoint machinery $(8,9)$. In this study, BubR1 upregulation caused microtubule disruption, as indicated by a significant increase in the percentage of cell cycle $\mathrm{G}_{2} / \mathrm{M}$ arrest. Results demonstrated an increase in BubR1 after HAC-Y6 treatment (Fig. 10A). We suggest that HAC-Y6 induced $\mathrm{G}_{2} / \mathrm{M}$ arrest and multinucleation via the accumulation of BubR1 protein.

Aurora kinases play important roles in chromosome alignment, segregation and cytokinesis during mitosis $(14,17,36)$. Our data showed decreased aurora A, phospho-aurora A, aurora B, phospho-aurora B and phospho-H3 expression after HAC-Y6 treatment (Fig. 10B). HAC-Y6, therefore, arrested the growth of COLO 205 cells at the $\mathrm{G}_{2} / \mathrm{M}$ phase and induced polyploidy through the inactivation of aurora kinases.

Apoptosis regulators provide the basis for novel therapeutic strategies aimed at promoting tumor cell death $(21,37)$. Mitochondria and Bcl-2 largely control intrinsic pro-apoptotic pathways. When mitochondria receive an apoptotic signal, their outer membranes become permeabilized, releasing Endo G, AIF, Apaf-1, cytochrome $c$ and procaspase-9, and into the cytosol and activating caspase- 3 through caspase- 9 , leading to apoptosis (38-40). Our data showed that these effects occurred after HAC-Y6 treatment (Fig. 11). Proteolytic degradation of PARP further demonstrated the involvement of caspase activation. These findings together suggest that HAC-Y6 might activate intrinsic signaling pathways.

The Bcl-2 family proteins largely mediate the mitochondrial apoptotic pathway $(41,42)$. Overexpression of Bcl-2 increases cell survival by suppressing apoptosis. Bax levels increase in conjunction with Bax inhibition of Bcl-2, and the cells undergo apoptosis. The present results showed increased Bax $6 \mathrm{~h}$ after HAC-Y6 treatment and decreased Bcl-xL and Bcl-2 $12 \mathrm{~h}$ after HAC-Y6 treatment (Fig. 12). HAC-Y6, therefore, induced apoptosis of COLO 205 cells through Bax activation and $\mathrm{Bcl}-\mathrm{xL}$ and $\mathrm{Bcl}-2$ inactivation.

Among our findings, HAC-Y6 significantly decreased levels of HSP90 in COLO 205 cells after a $2 \mathrm{~h}$ treatment (data not shown). HSP90 plays an essential role as a molecular chaperone for stress-accumulated misfolded proteins to prevent their aggregation $(7,43,44)$.

Fig. 13 summarizes the molecular signaling pathways induced by HAC-Y6. We demonstrated that HAC-Y6, a novel synthetic HSP90 inhibitor, exerts potent anticancer activity against COLO 205 cells through microtubule depolymerization, BubR1 activation, aurora A and aurora B inactivation, induction of $\mathrm{G}_{2} / \mathrm{M}$ arrest and polyploidy. HAC-Y6 also induces apoptosis of COLO 205 cells via intrinsic signaling pathways. These findings suggest that HAC-Y6 has potential use as a novel therapeutic agent for the treatment of human colon carcinoma.

\section{Acknowledgements}

This study was supported by a research grant from the National Science Council of the Republic of China, awarded to L.-J.H. (NSC 98-2628-B-039-018-MY3). Experiments and data analysis were performed, in part, through the use of the Medical Research Core Facilities Center, Office of Research and Development, China Medical University, Taichung, Taiwan, R.O.C.

\section{References}

1. Jemal A, Bray F, Center MM, Ferlay J, Ward E and Forman D: Global cancer statistics. CA Cancer J Clin 61: 69-90, 2011.

2. Ceelen W, Van Nieuwenhove Y and Pattyn P: Surgery and intracavitary chemotherapy for peritoneal carcinomatosis from colorectal origin. Acta Gastroenterol Belg 71: 373-378, 2008.

3. Watson AJ: An overview of apoptosis and the prevention of colorectal cancer. Crit Rev Oncol Hematol 57: 107-121, 2006.

4. Huang WW, Ko SW, Tsai HY, et al: Cantharidin induces G2/M phase arrest and apoptosis in human colorectal cancer colo 205 cells through inhibition of CDK1 activity and caspase-dependent signaling pathways. Int J Oncol 38: 1067-1073, 2011.

5. Sato S: Modulation of Akt kinase activity by binding to Hsp90. Proc Natl Acad Sci USA 97: 10832-10837, 2000.

6. Sreedhar AS, Sti C and Csermely P: Inhibition of Hsp90: a new strategy for inhibiting protein kinases. Biochim Biophys Acta 1697: 233-242, 2004.

7. Schmitt E, Gehrmann M, Brunet M, Multhoff G and Garrido C: Intracellular and extracellular functions of heat shock proteins: repercussions in cancer therapy. J Leukoc Biol 81: 15-27, 2007.

8. Morrow CJ: Bub1 and aurora B cooperate to maintain BubR1mediated inhibition of APC/CCdc20. J Cell Sci 118: 3639-3652, 2005.

9. Peters JM: The anaphase promoting complex/cyclosome: a machine designed to destroy. Nat Rev Mol Cell Biol 7: 644-656, 2006.

10. Jordan MA and Wilson L: Microtubules as a target for anticancer drugs. Nat Rev Cancer 4: 253-265, 2004.

11. Bhalla KN: Microtubule-targeted anticancer agents and apoptosis. Oncogene 22: 9075-9086, 2003.

12. Carvajal RD, Tse A and Schwartz GK: Aurora kinases: new targets for cancer therapy. Clin Cancer Res 12: 6869-6875, 2006.

13. Pérez Fidalgo J, Roda D, Roselló S, Rodríguez-Braun E and Cervantes A: Aurora kinase inhibitors: a new class of drugs targeting the regulatory mitotic system. Clin Transl Oncol 11: 787-798, 2009 . 
14. Fu J, Bian M, Jiang Q and Zhang C: Roles of aurora kinases in mitosis and tumorigenesis. Mol Cancer Res 5: 1-10, 2007.

15. Keen N and Taylor S: Aurora-kinase inhibitors as anticancer agents. Nat Rev Cancer 4: 927-936, 2004.

16. Carpinelli P, Ceruti R, Giorgini ML, et al: PHA-739358, a potent inhibitor of Aurora kinases with a selective target inhibition profile relevant to cancer. Mol Cancer Ther 6: 3158-3168, 2007.

17. Andrews PD: Aurora kinases: shining lights on the therapeutic horizon? Oncogene 24: 5005-5015, 2005.

18. Ruchaud S, Carmena M and Earnshaw WC: Chromosomal passengers: conducting cell division. Nat Rev Mol Cell Biol 8: 798-812, 2007.

19. Monaco L: Inhibition of Aurora-B kinase activity by poly(ADPribosyl)ation in response to DNA damage. Proc Natl Acad Sci USA 102: 14244-14248, 2005

20. Yasui Y: Autophosphorylation of a newly identified site of aurora-B is indispensable for cytokinesis. J Biol Chem 279: 12997-13003, 2003

21. Ghobrial IM, Witzig TE and Adjei AA: Targeting apoptosis pathways in cancer therapy. CA Cancer J Clin 55: 178-194, 2005.

22. O'Brien MA and Kirby R: Apoptosis: a review of pro-apoptotic and anti-apoptotic pathways and dysregulation in disease. $\mathrm{J}$ Vet Emerg Crit Care 18: 572-585, 2008.

23. Lawen A: Apoptosis? an introduction. BioEssays 25: 888-896, 2003.

24. Cai Y, Cai B, Cui CB, Zhang DY, Han B, Wang YG and Wang MW: Apoptosis-inducing effect of carbazole alkaloid (HY-1) in human erythroleukemia K562 cells. Zhonghua Zhong Liu Za Zhi 27: 457-460, 2005 (In Chinese).

25. Roy M: Mechanism of mahanine-induced apoptosis in human leukemia cells (HL-60). Biochem Pharmacol 67: 41-51, 2004.

26. Roy MK, Thalang VN, Trakoontivakorn G and Nakahara K Mahanine, a carbazole alkaloid from Micromelum minutum, inhibits cell growth and induces apoptosis in U937 cells through a mitochondrial dependent pathway. Br J Pharmacol 145: 145-155, 2005

27. Nafisi S, Malekabady ZM and Khalilzadeh MA: Interaction of $\beta$-carboline alkaloids with RNA. DNA Cell Biol 29: 753-761, 2010.

28. Mosmann T: Rapid colorimetric assay for cellular growth and survival: application to proliferation and cytotoxicity assays. J Immunol Methods 65: 55-63, 1983.

29. Chang YH, Hsu MH, Wang SH, et al: Design and synthesis of 2-(3-benzo[b]thienyl)-6,7-methylenedioxyquinolin-4-one analogues as potent antitumor agents that inhibit tubulin assembly. J Med Chem 52: 4883-4891, 2009.
30. Zhai D, Jin C, Huang Z, Satterthwait AC and Reed JC: Differential regulation of Bax and Bak by anti-apoptotic Bcl-2 family proteins Bcl-B and Mcl-1. J Biol Chem 283: 9580-9586, 2008.

31. Brunelle JK and Letai A: Control of mitochondrial apoptosis by the Bcl-2 family. Cell Sci 122: 437-441, 2009.

32. Tsai JY, Lin YC, Hsu MH, Kuo SC and Huang LJ: Synthesis and cytotoxicity of 1,6,8,9-substituted $\alpha$-carboline derivatives. Kaohsiung J of Med Sci 26: 593-602, 2010.

33. Tasi JY, Hung CM, Bai ST, et al: Induction of apoptosis by HAC-Y6, a novel microtubule inhibitor, through activation of the death receptor 4 signaling pathway in human hepatocellular carcinoma cells. Oncol Rep 24: 1169-1178, 2010.

34. Perez EA: Microtubule inhibitors: differentiating tubulininhibiting agents based on mechanisms of action, clinical activity, and resistance. Mol Cancer Ther 8: 2086-2095, 2009.

35. Yang J, Chen G, Hsia T, et al: Diallyl disulfide induces apoptosis in human colon cancer cell line (COLO 205) through the induction of reactive oxygen species, endoplasmic reticulum stress, caspases casade and mitochondrial-dependent pathways. Food Chem Toxicol 47: 171-179, 2009.

36. Yang J, Ikezoe T, Nishioka C, et al: AZD1152, a novel and selective aurora B kinase inhibitor, induces growth arrest, apoptosis and sensitization for tubulin depolymerizing agent or topoisomerase II inhibitor in human acute leukemia cells in vitro and in vivo. Blood 110: 2034-2040, 2007.

37. Lowe SW and Lin AW: Apoptosis in cancer. Carcinogenesis 21: 485-495, 2000

38. Green DR and Reed JC: Mitochondria and apoptosis. Science 281: 1309-1312, 1998.

39. Eberle J, Fecker LF, Forschner T, Ulrich C, Rowert-Huber J and Stockfleth E: Apoptosis pathways as promising targets for skin cancer therapy. Br J Dermatol 156 (Suppl 3): 18-24, 2007.

40. Dlamini Z, Mbita Z and Zungu M: Genealogy, expression, and molecular mechanisms in apoptosis. Pharmacol Ther 101: 1-15, 2004.

41. Bagci EZ, Vodovotz Y, Billiar TR, Ermentrout GB and Bahar I: Bistability in apoptosis: roles of $\mathrm{Bax}, \mathrm{Bcl}-2$, and mitochondrial permeability transition pores. Biophys J 90: 1546-1559, 2006

42. Antonsson B, Conti F, Ciavatta A, et al: Inhibition of Bax channel-forming activity by Bcl-2. Science 277: 370-372, 1997.

43. Pratt WB and Toft DO: Regulation of signaling protein function and trafficking by the hsp90/hsp70-based chaperone machinery. Exp Biol Med (Maywood) 228: 111-133, 2003.

44. Bai L, Xu S, Chen W, et al: Blocking NF-kappaB and Akt by Hsp90 inhibition sensitizes Smac mimetic compound 3-induced extrinsic apoptosis pathway and results in synergistic cancer cell death. Apoptosis 16: 45-54, 2011. 